\title{
The Tijaniyya Sufi Brotherhood Amongst the Idaw 'Ali of the Western Sahara
}

\author{
Winifred Marie Johnson*
}

\section{ORIGINS OF THE IDAW ALI}

The Idaw 'Ali are one of the two most prominent and influential zawaya groups in Mauritania, the other being the Kunta, disseminators of the Qadiriyya tariga in West Africa who claim to be descendants of the great Arab hero and conqueror of North Africa, Uqba b. Nafi. ${ }^{1}$ The basis of the prestige of the Idaw "Ali rested in part on their widely recognized sharifian origin. ${ }^{2}$ Another basis of their prestige was their introduction of the Tijaniyya tariqa in Mauritania. As descendants of Prophet Muhammed, the Idaw 'Ali occupied a noble and privileged position in the society that placed them above the other zawaya and lay groups in Mauritania.

The Idaw 'Ali traditions, as reported by Sidi Abd-allah b. al-Hajj Ibrahim al-'Alawi (d. 1818) in his treatise, "Sahihat al-Naql fi Alawiyat Idaw 'Ali wa Bakriyat Muhammed Ghull" (The Authenticity of the Descee Idaw 'Ali from Caliph 'Ali and that of Muhammed Ghull from Caliph 'Abu Bakr al-Siddiq), ${ }^{3}$ state unequivocally that the Idaw 'Ali

\footnotetext{
*Winifred Marie Johnson is a Research Scholar at Howard University, Washington, D.C. ${ }^{1}$ For more information on the Kunta, see Aziz Batran, "An Introductory Note on the Impact of Sidi al-Mukhtar al-Kunti on West African Islam in the Eighteenth and Nineteenth Centuries," Journal of the Historical Society of Nigeria 6, 4 (June 1973); "Sidi al-Mukhtar al-Kunti and the Recrudescence of Islam in the Western Sahara and Middle Niger," Ph.D. dissertation, University of Birmingham (November 1971); and "The Kunta, Sidi alMukhtar al-Kunti and the Office of Shaikh al-Tariqa al-Qadiriyya," in Studies in West African Islamic History, ed. J.R. Willis (London: Frank Cass, 1979).
}

${ }^{2}$ Sharif is a title given to a descendant of the Prophet. Throughout the Muslim world, shurufa are highly respected and honored. For further discussion, see The Shorter Encyclopedia of Islam, ed. J.H. Kramers (Ithaca, New York: Cornell University Press, 1953), pp. 529-533.

${ }^{3}$ Sidi Abdallah b. al-Hajj Ibrahim, "Sahihat al-Naql fi 'Alawiyat Idaw 'Ali wa Bakriyat Muhammed Ghull" [The Authenticity of the Descent of the Idaw 'Ali from Caliph 'Ali and that of Muhammed Ghull from Caliph "Abu Bakr al-Siddiq] trans. H.T. Norris in "The History of Shinqit According to the Idaw "Ali Tradition," Bulletin I.F.A.N. ser. B, 24 (1962): 393-413. 
descended from 'Ali b. 'Abu Talib (d. 661), son-in-law of the Prophet and fourth Caliph, through an eponymous ancestor 'Ali b. Yahya. Sidi Abdallah maintains that:

...the Idawa 'Ali are the descendants of'Ali b. Yahya and to be reckoned the progeny of 'Ali b. 'Abu Talib (May God be pleased with him). We know of no disagreement between those who are learned in that which has been handed down, both written and spoken, and those who have been favored with spiritual illumination regarding it. ${ }^{4}$

This genealogy is said to have been examined and declared sound by Sidi Mukhtar al-Kunti, the founding father of the Qadiriyya-Mukhtariyya brotherhood in West Africa. Furthermore, the author of "Sahihat alNaql" adduced numerous quotations which he related to genealogists and scholars of Mauritania and the Orient to prove the validity of the Idaw 'Ali's claim to sharifian ancestry.

Sidi Abdallah relates in "Sahihat al-Naql" that he was informed by Sidi Ahmed al-Daymani, the famed scholar of the Awlad Dayman zawaya group, that the Idaw 'Ali descended from the house of the Prophet. According to al-Daymani, the Idaw 'Ali

....are the progeny of 'Ali and ... both their young and their old continue to trace their lineage to him in spite of the paucity of that which God has allotted to them in support of their claim. ${ }^{5}$

Sidi Abdallah also relates that a member of the Idaw "Ali made the pilgrimage to Mecca where he met Sidi Ahmed al-Habib of the Idaw 'Ali. Sidi Ahmed is said to have told the pilgrim:

If you are in straightened circumstances, then say-oh forefather, oh Messenger of God-for in truth you are his descendant. ${ }^{6}$

The pilgrim asked Sidi Ahmed how he acquired this information concerning the lineage of the Idaw 'Ali, and Sidi Ahmed replied:

I saw that in a book in Cairo, but if you return there, ask Sheikh al-Murtada about the lineage of the people of Shinqit.

Sheikh al-Murtada is the saint of Egypt and its sun ... ${ }^{7}$

On the pilgrim's return journey he passed through Cairo and asked

IIbid., p. 396.

${ }^{5}$ Ibid., p. 394 .

${ }^{6}$ Ibid.

${ }^{7} \mathrm{Ibid}$. Shinqit is the name that the indigenous inhabitants of the Western Sahara call their region. It is named after the caravan and scholarly town of Shinqiti which the Idaw 'Ali claim to have founded. 
Sheikh al-Murtada about the lineage of the people of Shinqit without specifying any one group. Sidi Abdallah reported the conversation between the pilgrim and Sheikh al-Murtada as follows:

Muhammed b. "Ali b. "Abu Talib. . The pilgrim said to him,
"Sidi al-Habib told me that we are the offspring of Fatima."
"Did he say it?" He said, "Yes." Al-Murtada said, "This is what
I know."8

The genealogical records of the Idaw 'Ali state that a few of the descendants of Caliph 'Ali b. 'Abu Talib moved, at an unknown date, from Koufa in Iraq where Caliph 'Ali is interred, to Egypt, and then to Tlemcen in northwest Algeria. From there they filtered into the southwestern Algerian oasis of Tabalbalet, finally reaching the town of Abwayyar in Mauritania sometime in the second half of the twelfth century. ${ }^{9}$ It was in this town, according to the local traditions, that these descendants of Caliph 'Ali came to be known as the Idaw 'Ali. Sometime between 1223 and 1261 the Idaw 'Ali are said to have abandoned Abwayyar to settle in the new settlement which they founded, the farfamed town of Shinqiti.

There are no local, nor for that matter, external sources other than "Sahihat al-Naql" that report the migrations of the descendants of Caliph "Ali from Iraq through North Africa to Maritania. Moreover, "Sahihat al-Naql" neither gives the dates of these migrations, nor does it specify the factors that prompted them. Again, "Sahihat al-Naql" is rather uncertain as to which of the three sons of Caliph "Ali was the progenitor of the Idaw "Ali. At one point "Sahihat al-Naql"states that the Idaw 'Ali were the descendants of either Hassan or Hussein, the sons of Fatima, the Prophet's daughter and wife of Caliph 'Ali. Yet at another point "Sahihat al-Naql" maintains that the Idaw "Ali descended from Muhammed b. al-Hanafiya, Caliph 'Ali's son by a second wife known as al-Hanafiya. To lend credibility to this confused story, "Sahihat al-Naql" states that one of the sons of Muhammed b. al-Hanafiya married one of his cousins, a daughter of Hassan. It was through the offspring of these two grandchildren of Caliph "Ali that the Idaw "Ali thus claim descent. ${ }^{10}$

Such confusion and ambiguity in "Sahihat al-Naql", as well as in other Idaw "Ali traditions, raise serious doubts as to the authenticity of the Idaw 'Ali's claim to sharifian descent. Indeed, one is tempted to conclude that this early part of the Idaw 'Ali was perhaps fabricated and

${ }^{8}$ Ibid.

9Sidi Abdallah, "Sahihat al-Naql." p. 398; Paul Marty, Etudes sur l'Islam Maure (Paris: Ernest Leroux, 1916), p. 203; P. Amilhat, "Petite Chroniques des Id ou Aich, Annexe 2," Revue des Etudes Islamiques 1 (1937): 112.

${ }^{10 S i d i}$ Abdallah, "Sahihat al-Naqh," pp. 396-97, 402. 
deliberately concocted for the sole purpose of elevating the group to a lofty and honorable status, that of shurufa. Furthermore, one tends to agree with P. Amilhat's suggestion that the Idaw 'Ali were Zanata Berbers in origin and had no sharifian blood running in their veins. ${ }^{11}$ Paul Marty, on the other hand, states that the Idaw 'Ali descended from a western Saharan eponymous ancestor, 'Ali b. Belhamar, who is said to have lived either around 1350 or $1500 .{ }^{12}$ If this was true, the Idaw 'Ali would have gotten their name "Idaw 'Ali" (sons of 'Ali) from a western Saharan figure, possibly Berber in origin, rather than from Caliph 'Ali.

The Idaw 'Ali's claim to sharifian descent remained unchallenged by the people of Mauritania. Their alleged sharifian ancestry became part of their heritage, and thus one of the basis, perhaps the most essential basis, of their noble social standing in Mauritania. Indeed, it confirmed their claim to the political and religious leadership in the town of Shinqiti.

\section{THE IDAW 'ALI AND THE TIJANIYYA}

A tradition of the Idaw "Ali relates that "an Idaw "Ali cannot be but a Tijani." ${ }^{13}$ Indeed, by 1830 the Tijaniyya had become a way of life, a sort of "National religion," and a mark that set them apart from affiliates of other turuq (Sufi brotherhoods), particularly the Qadiriyya, with its western Saharan branches of the Mukhtariyya (Bakkayya), the Fadiliyya and the branch of Awlad Ibiri.

A Tijaniyya tariqa was founded by an Algerian, Ahmed b. Muhammed al-Tijani (1737-1815). In 1800-1801 Ahmed al-Tijani founded in Fas, Morocco, a zawiya where he taught Sufism and initiated disciples (murids, talamidh) into his tariqa, the Tijaniyya. ${ }^{14}$ Upon their acceptance of the Tijaniyya, the disciples received the Tijani wird (pl. awrad, Sufi litany) and were obliged to renounce other turuq. In fact, once a disciple accepts the Tijani wird he is not allowed to become a member of another order. Tijaniyya doctrines stipulate that:

[The murid] should absolutely abstain from any other awrad than those of his [Tijani] sheikh, since Allah did not crate two hearts within him. . . . [The murid] must not desist from reciting the awrad as long as he lives, because they contain the mysteries of the Creator. ... He must not criticize any good thing that seems strange to him in this Tijani tariqa, or he will be deprived of their virtue by the Just Ruler. He should not

\footnotetext{
${ }^{11}$ Amilhat, "Petite Chroniques des Id ou Aich," p. 112.

${ }^{12}$ Marty, Etudes sur l'Islam Maure, p. 204.

${ }^{13}$ This tradition is quoted by Paul Marty in Etudes sur l'Islam Maure, p. 216.

${ }^{14}$ Jamil Abun-Nasr, The Tijaniyya (London: Oxford University Press, 1965), p. 51.
} 
recite the wird except after permission and proper initiation. . . 15

The Tijani wird is recited twice every day, in the morning and in the evening. It consists of three parts. The first part is the formula of penitence, أستغف الذ (Astaghfiru Allah, or "I beg forgiveness of Allah"), which is to be recited one hundred times. The second is a prayer for the Prophet Muhammed called تفاتخ (Salat al-Fatih). The text of this Salat al-Fatih runs as follows:

O God, bless our master Muhammed who opened what had been closed, and who is the seal of what had gone before; he who makes the Truth victorious by the Truth, the guide to Thy straight path, and bless his household as is the due of his immense position and grandeur.

Salat al-Fatih is also recited one hundred times. The third part is the formula of Hailalah, that is all لy (La ilaha illa Alah, or "There is no god but Allah"). The Hailalah is repeated one hundred times. ${ }^{16}$

By receiving this wird from an authorized Tijani sheikh, the initiate would give up his membership in other Sufi turuq. And once he becomes a member of the Tijaniyya, he is warned against repudiating it, for "it is widely believed among the Tijanis that a Muslim who leaves their order [the Tijaniyya] 'would have an adverse termination of his life' (yamutu 'ala su' al-khatima)." ${ }^{17}$ However, if the affiliate remains a Tijani he is said to be assured of Ahmed al-Tijani's intercession on his behalf with Allah, and thus guaranteed Allah's Grace and Paradise, for Ahmed alTijani has assured his followers that he was the channel of the Divine Grace. ${ }^{18}$ It thus appears that denunciation of other brotherhoods and other sheikhs by the Tijanis stemmed fromt he belief amongst them that their tariqa was not only superior to other turuq, but that it abrogated other turuq, in the same way that the Prophet Muhammed had taught that Islam abrogated other religions.

It was this particularism and exclusiveness of the Tijaniyya that proved to be an obstacle to the recruitment of adherents, particularly in areas where other turuq had already established their influence. ${ }^{19}$

${ }^{15 J}$. Spencer Trimingham, The Sufi Orders in Islam (London: Oxford University Press, 1971), p. 191, quoting Muhammed Alwan al-Jawsqi, As-Sir al-abhar fi awrad Ahmed alTijani, p. 3.

${ }^{16}$ Abun-Nasr, The Tijaniyya, p. 51.

${ }^{17}$ ibid., p. 39.

${ }^{18}$ Ibid., pp. 34, 43 and 45. Ahmed al-Tijani's intercession is said to have extended to all who saw him, even if they were infidels. It is said that if an infidel saw Ahmed al-Tijani, especially on a Friday or Monday, he would die a Muslim.

${ }^{19}$ The Qadiriyya does not prohibit its affiliates from receiving the awrad from other turuq, provided that these affiliates did not denounce the Qadiriyya. See Batran, "Sidi Mukhtar al-Kunti," p. 231. 
Indeed, the Idaw 'Ali faced insurmountable difficulties in their effort to initiate disciples into the Tijaniyya in the western Sahara, the area which had been under the influence of the Kunta and the Qadiriyya for decades.

Other Tijani doctrines and rituals were criticized and attacked by the sheikhs of other turuq and were found to be detrimental to popular acceptance of the Tijaniyya. One of these doctrines was the claim that Ahmed al-Tijani was ختم (Khatm al-Wilaya alMuhammadiyya, or the seal of Muhammedan sainthood, that is, the ultimate saint). ${ }^{20}$ This claim arrogated to Ahmed al-Tijani supremacy over all other Muslim saints, living or dead, in the same way that the Prophet Muhammed, being خت الخنبياء (Khatm al-Anbyya, or the seal of Prophethood, that is the last Prophet) is held by the Muslims to be superior to all the prophets who preceded him. ${ }^{21}$

Ahmed al-Tijani also claimed for himself عصمة ('isma, impeccable infallibility), which the Muslims attribute to the prophets but not to the saints. The claim of 'isma placed Ahmed al-Tijani in a class of his own vis-a-vis all saints and sheikhs of the established Sufi turuq. Significantly the Qadiriyya (Mukhtariyya) of Mauritania and West Africa could not concede 'isma to Ahmed al-Tijani, for sheikh Sidi Mukhtar al-Kunti had taught that isma was an attribute of the prophets, while be (hifz, preservation from sin)was an attribute of saints. ${ }^{22} \mathrm{Al}$-Mukhtar al-Kunti is said to have asserted that:

It could not be said that a wali [saint] is fallible. . for to say so would place him on equal footing with the average people, and he is above them in this respect; nor could he be described as infallible either, for that would put him in the class of the prophets, to which distinction he is not entitled. ${ }^{23}$

Two Tijani rituals were found to be particuarly repugnant to the Kunta Qadiris. These were sama' (dancing and singing), also known as rags (dancing), and the prohibition of ziara (visitation to living saints and the tombs of dead ones). ${ }^{24}$ Sama' (raqs), which is part of dhikr (perpetual recollection by heart and tongue of the names of Allah) is performed communally by the Tijanis on Fridays following the obligatory afternoon prayer. Tijani followers chant in unison "La ilaha illa Allah" or simply "Allah Allah" to the accompaniment of duffs

\footnotetext{
${ }^{20}$ Abun-Nasr, The Tijaniyya, pp. 28-35.

${ }^{21}$ Ibid.

22Batran, "Sidi al-Mukhtar al-Kunti," p. 137.

${ }^{23}$ Abun-Nasr, The Tijaniyya, pp. 35-36, quoting Sidi Muhammed b. al-Mukhtar al-Kunti, Kitab al-Tara'if, pp. 92-93.

${ }^{24}$ For a fuller discussion of sama' and ziara, see Abun-Nasr, The Tijaniyya, pp. 39-4, 53, 56; and Batran, "Sidi Mukhtar al-Kunti," pp. 215, 217, 231.
} 
(tamborine-shaped drums). ${ }^{25}$ The Kunta Qadiris however denounced this Tijani communal dhikr and sama', insisting that the dhikr is a private affair performed by affiliates individually and in complete silence within the precincts of khalwa (retreat or seclusion). In the words of the grandson of Sidi Mukhtar al-Kunti:

We the Qadiris do not approve of sama' [raqs], frivolous playing and merry-making because they are degrading to man's dignity and damaging to his honor. ${ }^{26}$

Although the Tijanis prohibited ziara, ${ }^{27}$ the mausoleum of Ahmed alTijani has become for them a place of pilgrimage to which affiliates from North Africa, West Africa and elsewhere came to pay homage to their Spiritual Guide and gain his baraka. The prohibition of ziara to tombs other than that of Ahmed al-Tijani is held by affiliates of other turuq as placing their venerated saints in an inferior position to that of Ahmed al-Tijani and reducing them to the status of common folk. No wonder, then, that the Kunta Qadiris denounced the Tijani prohibition of ziara and insisted that Muslims were free to visit the tombs of all saints to gain their baraka and spiritual blessings. ${ }^{28}$

The person who was responsible for introducing the Tijaniyya (the Tijani wird) amongst the Idaw 'Ali was Sheikh Muhammed al-Hafiz b. al-Mukhtar b. Lahbib al-'Alawi (d. 1830), who belonged to the Idaw 'Ali al-Kuhul of Trarza. The biography of Muhammed al-Hafiz and his meeting with Ahmed al-Tijani, who is said to have personally initiated him into the Tijaniyya, is told by Sheikh Muhammed al-Arabi. Muhammed al-Arabi, in pious and glowing terms that ascribe miraculous powers, sanctity and virtues to Muhammed al-Hafiz, states in his book Bughyat al-Mustafid that:

Sidi Muhammed al-Hafiz al-'Alawi al-Shinqiti, may Allah sanctify his secret, was the saint under whom this lofty tariqa [the Tijaniyya] spread in the far west [the western Sahara]. His glorious deed are numerous and countless. Having completed his formal studies [in Mauritania] and having become an Imam of note and a scholar of great repute, he left [Mauritania] on pilgrimage to visit the sacred house of Allah and the tomb of His Prophet, may Allah be pleased with him. One of his sincere intentions on this journey was to meet a complete sheikh [sheikh kamil] from amongst the people of

\footnotetext{
${ }^{25}$ Abun-Nasr, The Tijaniyya, pp. 54-55.

${ }^{26}$ Batran, "Sidi Mukhtar al-Kunti," pp. 215-217, quoting Ahmed al-Bakkayy b. Muhammed b. Sidi al-Mukhtar, Fath al-Quddus, p. 32.

${ }^{27}$ Abun-Nasr, The Tijaniyya, pp. 39-40.

${ }^{28}$ Batran, "Sidi Mukhtar al-Kunti," passim.
} 
Allah. On the pilgrimage caravan he met a man from Sijilmasa. They became close freinds and in due course they disclosed their intentions [to find a complete sheikh] to each other. It so happened that their intentions concurred. ${ }^{29}$

The two pilgrims continued their journey to Mecca, and promised to inform each other if one of them should find the sheikh for whom they searched. Al-'Arabi continues to say:

When they arrived in Mecca al-Sheikh al-Hafiz, may Allah have mercy on him, spared no effort in looking for a complete sheikh. One day while in tawaf [the circumambulation of the Ka'aba] he was approached by a man who told him that his sheikh was Ahmed al-Tijani. That was the first time ever that Muhammed al-Hafiz heard of Ahmed al-Tijani. He then hurried to his friend from Sijilmasa to inform him that the sheikh they were looking for was Ahmed al-Tijani. ${ }^{30}$

$\mathrm{Al}-\mathrm{Hafiz}$ and his friend from Sijilmasa then inquired from amongst the pilgrims about Ahmed al-Tijani, searching from camp to camp for more information on this sheikh. Al-Arabi states that:

...they arrived at [the camp of] the pilgrims from the Maghrib [Morocco]. They were told to look up the pilgrims from Fas. At first they met some common folk from Fas who said to them that they knew of Ahmed al-Tijani and that he was a man of secular sciences. However, one of these common folk told them to inquire from another group from $\mathrm{F}$ as and found them to be men of character and piety. They asked them about al-Tijani, upon which they answered that al-Tijani was a man of great learning and sanctity. They also told the two friends that there was a companion of al-Tijani in Mecca by the name of Sidi Ali Harazim and advised them to consult with him. It was from [this Ali Harazim] that the two friends received complete information about al-Tijani. Muhammed al-Hafiz was so impressed by what he heard from Ali Harazim that he decided to journey to Fas and meet Ahmed al-Tijani. ${ }^{31}$

It appears that Muhammed al-Hafiz visited Fas in the 1790's on his way home frm the pilgrimage. It is not known for how long he stayed with Ahmed al-Tijani in Fas. However, towards the end of his stay

${ }^{29}$ Muhammed al-'Arabi al-Sa'ih, Baghyat al-Mustafid li-Sharh Munyat al-Murid fi alTariqa al-Tijaniyya, trans. Aziz Batran (Cairo: al-Hajj Mustafa Muhammed Press, 1356 A.H.), p. 192; and Ahmed b. al-Alyashi Sukayraj, Kashf al-Hijab amman talaqa ma alShaikh al-Tijani min al-Ashab, trans. Aziz Batran (Cairo: 1961-62), pp. 355-356.

${ }^{30} \mathrm{Ibid}$.

${ }^{31} I$ bid. 
Ahmed al-Tijani conferred upon hm the Tijani wird, thus initiating him into the Tijaniyya. It is also said that al-Hafiz received al-ijaza almutlaqa (free licence) from Ahmed al-Tijani which gave him unrestricted authority to confer the Tijani wird and initiate members into the tariqa. However, it is said that Ahmed al-Tijani restricted Muhammed al-Hafiz to the appointment of ten muqaddams (deputies). Most significantly, just before his death in 1815, Ahmed al-Tijani is claimed to have appointed seven khalifas (successors), each over a specific area. One of these was Muhammed al-Hafiz whom Ahmed alTijani nominated khalifa over "the country of the Berbers and Sudan." 32

Having bid his mentor Ahmed al-Tijani farewell, Muhammed alHafiz returned to his homeland in Trarza in central Mauritania. There, he gathered around him numerous disciples, mainly from his own group, the Idaw 'Ali, whom he instructed in the Tijaniyya teaching. The task before him was formidable. For al-Hafiz to succeed in his efforts in planting the Tijaniyya in the western Sahara he had to cultivate a soil that had already been exhausted by the Qadiriyya (Mukhtariyya).

The Qadiriyya (Mukhtariyya) was introduced into Walata in the Hodh region of Mauritania by a Kunta sheikh, Sidi Ahmed Bakkayy Bu Dam (d. 1515). ${ }^{33}$ Although Bu Dam's descendants carried on his work in propagating the Qadiri wird in the western Sahara and the Niger bend, it was not until the time of Sidi al-Mukhtar al-Kunti(1715-1811) that the entire region of Mauritania nad the Niger bend succumbed to the Qadiriyya-Mukhtariyya influence. ${ }^{34}$ Sidi al-Mukhtar's work was carried on by his descendants, as well as by his telamidh, most eminent amongst whom were sheikh Sidiyya al-Kabir (d. 1868) and Muhammed Fadl (d. 1869). By the time Muhammed al-Hafiz started to disseminate the Tijani wird in the western Sahara he found the Qadiriyya already well entrenched in the area. Although the Idaw 'Ali claim that prior to their acceptance of the Tijaniyya they did not belong to any tariqa, particularly the Qadiriyya, evidence indicates that the Qadiriyya was widely spread amongst them..$^{35}$ Muhammed al-Hafiz therefore had to lure away Qadiri affiliates to the Tijaniyya.

At first Muhammed al-Hafiz had very little success. His biographer al-'Arabi, however, does not concede to this fact. Instead of admitting initial failure on the part of al-Hafiz, al-Arabi explains that al-Hafiz did

32J.R. Willis, "Al-Hajj Umar b. Said al-Futi al-Turi and the Doctrinal Basis of His Islamic Reformist Movement in the Western Sudan," Ph.D. dissertation, University of London, School of Oriental and African Studies (January 1970). The other six khalifas were: Muhammed al-Ghali Abu Talib al-Tijani al-Husni; Muhammed b. al-'Arabi; al-Hajj alHarazim; Muhammed b. al-Mushri; Mahmud al-Tunsi al-Tamasini; and al-Fadl alMufdali al-Fasi.

${ }^{33}$ Batran, "The Kunta, Sidi al-Mukhtar al-Kunti and the Office of Shaikh," p. 121.

${ }^{34}$ Batran, "An Introductory Note on the Impact of Sidi al-Mukhtar al-Kunti," p. 243. ${ }^{35}$ Marty, Etudes sur l'Islam Maure, p. 218. 
not initiate members into the Tijaniyya because he was advised by Ahmed al-Tijani that he "should not reveal himself until Allah reveals him to the people." 36

Al-Arabi maintains that it was only after Muhammed al-Hafiz received a spiritual call that al-Hafiz started to preach the Tijani wird and to initiate members into the Tijaniyya. He states that:

One day after al-Hafiz had finished the afternoon prayers and started to teach his telamidh, a man who was known for his righteousness and his frequent communication with the Prophet al-Khadir (peace be upon him) arrived at al-Hafiz's majlis [study circle]. The man was then introduced to al-Hafiz. Al-Hafiz welcomed him and asked him to sit beside him. The man refused to sit beside al-Hafiz, preferring to sit at his feet. He then asked al-Hafiz, "Do you know why I came to you?" AlHafiz replied, "No, I don't know." The man continued, "I came to you to receive from you all that you have brought from the Tell [the north, that is, Fas] and which you are keeping in trust." Al-Hafiz responded, "And what did I bring from the Tell? I only brought some books. If you are interested in some of them I will give them to you to keep." The man said, "That is not necessary, Oh Master. I came here to receive from you the wird of al-sheikh al-Tijani (may Allah be pleased with him)." ${ }^{37}$

Al-Arabi claims that al-Hafiz immediately granted the Tijani wird to that man. Everyone who was present in the majlis likewise asked for the wird and was given it. According to al-Arabi:

All who received the wird then left for their families and told them of the story of the man who came to receive the Tijani wird from al-Hafiz. The news of this incident quickly travelled from house to house, and by daybreak numerous people flocked to al-Hafiz to receive the Tijani wird from him. People continued to flock to al-Hafiz from near and far, so much so that the tariqa [the Tijaniyya] achieved such great popularity..$^{38}$

Understandably, al-Arabi's account of al-Hafiz's success in spreading the Tijaniyya was no doubt an exaggeration, because it came from a Tijani source. In fact, for about thirty years al-Hafiz was only able to win over to the Tijaniyya his own group, the Idaw 'Ali, their clients (ahlaf) and tributaries (znaga), as well as some individuals and a few families from other groups. Al-Hafiz's success among his own group the Idaw

\footnotetext{
${ }^{36} \mathrm{Al}-$ Arabi, Bughyat, p. 192.

${ }^{37}$ Ibid., pp. 192-193.

${ }^{38}$ Ibid., p. 193.
} 
'Ali, however, was phenomenal, for by the time of his death in 1830 it is claimed that the entire Idaw 'Ali group accepted the Tijaniyya. ${ }^{39}$ AbunNasr states that:

The missionary work of Muhammed al-Hafiz was very successful, so that before he died in about 1830 it became customary to consider every member of the tribe a follower of the Tijaniyya order. As the Idaw 'Ali was the only tribe in Mauritania which was completely converted to the order, the Tijaniyya became, so to speak, its national faith. . . .40

Although Abun-Nasr and Paul Marty believe that al-Hafiz's missionary activities were essential in winning over the Idaw 'Ali to the Tijaniyya, they nevertheless emphasize that the Idaw 'Ali accepted the Tijaniyya for different reasons. Abun-Nasr claims that by the time of the return of al-Hafiz from $\mathrm{Fas}$ the ancient animosity between the different branches of the Idaw 'Ali had completely died out and that friendly contacts and intermarriage between them "facilitated the spread of the Tijaniyya throughout the entire tribe after it was first introduced among the Idaw 'Ali of Trarza [by Muhammed al-Hafiz]." 41 Paul Marty, on the other hand, believed that the Idaw 'Ali adopted the Tijani wird because the Idaw 'Ali believed that the Tijaniyya was younger and less widespread than other turuq. ${ }^{42}$

Notwithstanding these explanations proffered by Marty and AbunNasr, the Idaw 'Ali attachment to the Tijaniyya seems to be a revolt against the supremacy of the Qadiriyya and the Kunta. The Tijaniyya gave the Idaw 'Ali independence from the Kunta and put them on par with them. Their sense of superiority as shurufa and as a premier zawaya group in the western Sahara was hence enhanced by their being the sheikhs of a tariqa that owes its introduction into the area to one of their members, Muhammed al-Hafiz. By rejecting the Qadiriyya and accepting the Tijaniyya the Idaw 'Ali no longer owed allegiance to the Kunta sheikhs, but to sheikhs from amongst themselves. In this way the Idaw "Ali would say to the Qadiris in Mauritania that they had "always been independent and without affiliation to any tariqa." 43

Besides the Idaw 'Ali, only two other groups in Mauritania could claim to be wholly won over to the Tijaniyya. These were the Idaw 'Ali znaga tributaries (Awlad Abd al-Wahhab, Awlad sheikh Mbarak, ould Zin alDin lam Nasir, and Awlad sheikh Jadoub ould Muhammed ould alHafiz) and their ahlaf, the Aghlal. With their acceptance of the

${ }^{39}$ Marty, Etudes sur l'Islam Maure, p. 215; and Abun-Nasr, The Tijaniyya, p. 103.

${ }^{40}$ A bun-Nasr, The Tijaniyya, p. 103, quoting Paul Marty, Etudes surl'Islam Maure, p. 217.

${ }^{41} I$ bid., p. 103.

${ }^{42}$ Marty, Etudes sur l'Islam Maure, p. 218.

43Ibid., p. 217. 
Tijaniyya, the Idaw 'Ali no longer called them znaga and ahlaf, but Lemradin (murids or disciples) and cousins, respectively, euphemisms that raised them in the eyes of the people of Mauritania from an inferior status of tributaries and clients to a higher one.

Outside the Idaw "Ali "camp," al-Hafiz was also able to initiate important personalities and families from the Idaw Yaqub, Awlad Dayman, and the Tashidbit, all of which groups were zawaya that were previously attached to the Qadiriyya. These inroads that the Tijaniyya made into the bases of Kunta Qadiriyya influence aroused the consternation of the Qadiri sheikhs and prompted the great Qadiri sheikh and philologist Idyyja b. Abdallah al-Kamlili to write satirical poems ridiculing the Idaw "Ali and the Tijaniyya. ${ }^{44}$ It is claimed that al-Hafiz forbade any response to be made to al-Kamlili's attacks. It was only after al-Hafiz's death that sheikh Sidi Muhammed b. al-Saghir, a student of Sidi Bamn, a fourth generation Tijani, wrote his book al-Jaish al-Kabir ${ }^{45}$ in defense of the Tijaniyya as an answer to al-Kamlili.

Amongst the eminent students of al-Hafiz who were remembered by the Tijanis of Mauritania were his wife Fatima, his cousin and brotherin-law Sidi Muhammed ibn Sidi Abdallah ibn Alfagh Alfaqaqi, and Sidi Mawlud Fal. ${ }^{46}$ Of these three disciples, it was Sidi Mawlud Fal who is credited with the spread of the Tijaniyya amongst the Toucoulears, the Wolof and the Sarakolle of Senegal. Mawlud $\mathrm{Fal}$ belonged to the Idaw Yaqub zawaya. It is said that he visited as to study under Ahmed alTijani, but on his arrival he found that the great sheikh was already dead. Consequently he went back to Mauritania to sit at the feet of Muhammed al-Hafiz who initiated him into the Tijaniyya tariga. ${ }^{47} \mathrm{He}$ became one of the most fervent disciples of al-Hafiz, leaving an everlasting impression on his mentor so much so that al-Hafiz gave him his sister in marriage.

Many important West African Tijanis trace their affiliation to the Tijaniyya through Mawlud Fal. Of these, two West African sheikhs figured significantly in disseminating the Tijaniyya amongst the peoples under their influence. The first sheikh was the West African jihadist, al-Hajj Umar Tall (d. 1864), whose silsila (chain of ascription) connects him with al-Hafiz through Umar's teacher, sheikh Abdul Karim b. Ahmed al-Naqil, who in turn was initiated into the Tijaniyya

\footnotetext{
"Ahmed al-Amin al-Shinqiti, al-Wasit fi tarajim udaba Shinqiti (Cairo: al-Khanji, 1961), p. 398.
}

${ }^{45}$ Al-Ahinqiti, al-Wasit, p. 89; al-'Arabi, Bughyat, p. 193; and Sukayraj, Kashf al-hijab, p. 357. Muhammed al-Saghir was initiated into the Tijaniyya by Muhammed Banm, known as ould Hammu Khtar, who was initiated by al-Hafiz's disciple Mawlud Fal. His book alJaish al-Kabir is published in Fas and Cairo, but no date of publication is given.

${ }^{46} \mathrm{Al}$-'Arabi, Bughyat, p. 193.

${ }^{47}$ Marty, Etudes sur l'Islam Maure, pp. 222-223. 
by Mawlud Fal. ${ }^{48}$ The second sheikh was al-Hajj Malik Si (d. 1922), who received the Tijani wird from his maternal uncle Mayoro, who had in turn been introduced into the Tijaniyya by Mawlud Fal. ${ }^{49}$

Al-Hafiz was succeeded in the direction of the Tijaniyya by his son Ahmedu who died at an advanced age in 1907, and then by his grandson Muhammed Said b. Ahmedu b. Muhammed al-Hafiz. ${ }^{50}$ Both khalifas continued al-Hafiz's work in the spreading of the Tijani wird. They attracted numerous disciples whom they won over to the Tijaniyya and sent Tijani missionaries into Bilad al-Sudan to spread the Tijaniyya. Today, the Idaw 'Ali Tijani sheikhs can be found in many parts of West Africa, teaching Islamic sciences and attracting initiates from Senegal, Gambia, Guinea, Sierra Leone and Mali into the Tijaniyya. These sheikhs were peripatethic, carrying out siyaha (religious tours) with no permanent religious schools or centers.

\footnotetext{
${ }^{48} \mathrm{Al}-\mathrm{Hajj}$ Umar's jihad and his efforts in disseminating the Tijaniyya are well known. For a more complete discussion on al-Hajj Umar, see J.R. Willis, "Al-Hajj Umar b. Said al-Futi al-Turi”; West African Resistance ed. Michael Crowder (London: Hutchinson and Co., Ltd., 1971); History of West Africa vol. 2 (New York: Columbia Press, 1973); B.O. Oloruntimehin, The Segu Tukulor Empire (New York: Humanities Press, 1972); and Omar Jah, "Sufism in Nineteenth Century Jihad Movements in West Africa: A Case Study of alHajj Umar Futi's Philosophy of Jihad and Its Sufi Basis", Ph.D. dissertation, Department of Islamic Studies, McGill University, Montreal, 1974).

${ }^{49} \mathrm{~F}$ or further discussion of al-Hajj Malik Si, see Marty, Etudes sur l'Islam au Senegal and Etudes sur l'Islam Maure.
}

${ }^{50}$ Marty, Etudes sur l'Islam Maure, pp. 216, 219. 